Erratum

\title{
Cloning and characterization of a pathogen-induced chitinase in Brassica napus
}

Ulla Rasmussen $^{1,3}$, Kirsten Bojsen ${ }^{2}$ and David B. Collinge ${ }^{1}$

${ }^{1}$ Plant Biology Section, Environmental Science and Technology Department, Risø National Laboratory, P.O. Box 49, DK-4000 Roskilde, Denmark; ${ }^{2}$ Maribo Seed Biotechnology Copenhagen, Danisco A/S, Langebrogade 1,DK-1001 Copenhagen K, Denmark; ${ }^{3}$ Present address: Botaniska Institutionen, Stockholms Universitet, S-1069 Stockholm, Sweden

Plant Molecular Biology 20: 277-287, 1992.

In Fig. 5 of this paper, the lanes were incorrectly marked. The correct figure is as follows:

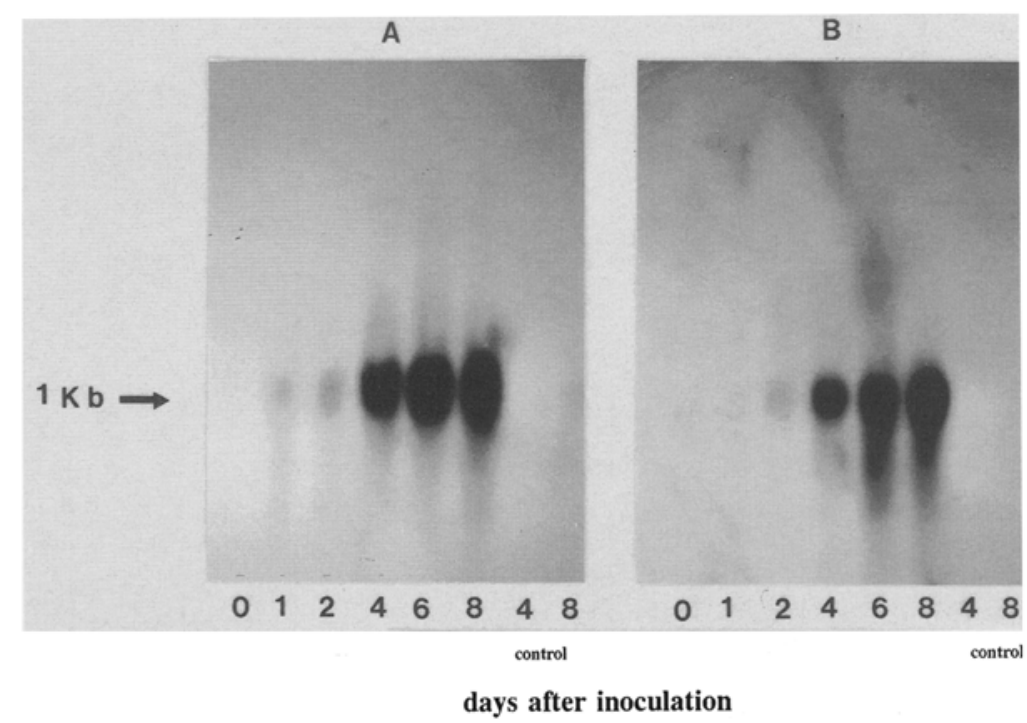

Erratum

\section{The expression of a $r a b$-related gene, $r a b 18$, is induced by abscisic acid during the cold acclimation process of Arabidopsis thaliana (L.) Heynh.}

Viola Lång and E. Tapio Palva

Department of Molecular Genetics, Uppsala Genetic Center, Swedish University of Agricultural Sciences, Box 7003, S-750 07 Uppsala, Sweden

Plant Molecular Biology 20: 951-962, 1992.

When issue 20:5 was being printed, Fig. $2 \mathrm{c}$ of the above-mentioned paper was erroneously deleted from the page. The printers apologize for this error and herewith place it as it should have been: 